\title{
KONSEP "BALDATUN THOYIBATUN WA ROBBUN GHOFUR" SEBAGAI TUJUAN AKHIR PROSES TRANFORMASI SOSIAL ISLAM
}

\author{
Sabdo \\ UNIVERSITAS MUHAMMADIYAH METRO \\ Jl. Ki hajar Dewantara 15 A Imopuro Metro Timur Kota Metro
}

\begin{abstract}
A term often heard, read or discourse is "Baldatun Thoyibatun warobbun Ghofur" in Indonesian terms defined as a good country God forgave, or in Javanese philosophy "gemah ripah loh jinawi". The above phrase is the term that has been built by the Qur'an as hudan (guidance) for those who are devoted. The concept of the State above is very often an interesting discourse but in the level of reality has not been able to answer various problems in this country

In the process of social transformation, Baldatun Thoyibatun warobbun Ghofur is as the final destination, the birth of a society full of peace, prosperity and justice, a perfect spiritual or material society. Specifically, the process of Islamic social transformation is the existence of a da'wah movement that continues to strive for change, from the darkness of life (al-Dzulumat) to a radiant life (al Nur), from ignorance to Islam. A question arises whether this desirable country has been seen? and whether the current da'wah has not been able to give birth to it? of the two questions arise several problems; If the country of desire has been born what it looks like? If the da'wah has not been able to realize the country of desires, what is the problem? The above questions should be examined, for "baldatun Thoyibatun warobbun Ghofur is a necessity.

The method used in studying this problem is the library study (library research) which prioritizes the review of the sources, then analyzed the texts to produce conclusions.

This study can be concluded that the Baldatun thoyibatun warabbun ghofur state is a prosperous country in every field, because it is based on the basis of monotheism. Both the social, cultural, political, economic, educational and human rights fields. In realizing the form of the State requires a stage which should be noticed by the actors of change, as the Prophet (s) made a change. These changes can be made by making internal and external changes.
\end{abstract}

Key Word: Baldatun Toyibatun Warabbun Ghofur, Transformation 


\section{A. PENDAHULUAN}

Sebuah istilah yang sering didengar, dibaca ataupun diwacanakan adalah " baldatun Thoyibatun warobbun Ghofur"dalam istilah Indonesia didefinisikan sebagai negeri yang baik yang diampuni Tuhan, atau dalam falsafah Jawa "gemah ripah loh jinawi". Ungkapan diatas adalah term yang telah dibangun oleh Al Qur'an sebagai hudan (petunjuk) bagi orang-orang yang bertaqwa. Konsep Negara diatas sangat sering menjadi diskursus yang menarik akan tetapi dalam tataran realita belum mampu menjawab berbagai masalah dinegara ini.

Dalam proses transformasi sosial, baldatun Thoyibatun warobbun Ghofur adalah sebagai sebagai tujuan akhir, lahirnya suatu masyarakat yang penuh dengan kedamaian, kemakmuran dan keadilan, masyarakat yang sempurna spiritual ataupun material. Secara spesifik, proses transformasi sosial islam adalah adanya suatu gerakan dakwah yang terus berjuang melakukan perubahan, dari kehidupan kegelapan(al Dzulumat) menuju pada kehidupan yang bercahaya (al Nur), dari kebodohan (jahiliah) menuju Islam . timbul suatu pertanyaan apakah negri dambaan ini telah nampak ? dan apakah dakwah saat ini belum mampu melahirkanya ? dari dua pertanyaan tersebut muncul beberapa masalah ;

1. Jika negeri dambaan itu telah lahir seperti apakah bentuknya ?

2. Jika dakwah belum mampu merealisasikan negeri dambaan apa masalahnya?

Pertanyaan-pertanyaan diataslah yang hendaknya dikaji, karena "baldatun Thoyibatun warobbun Ghofur adalah suatu keniscayaan .

Mungkin dapat dibuat sebuah paradigma berfikir dalam makalah ini :

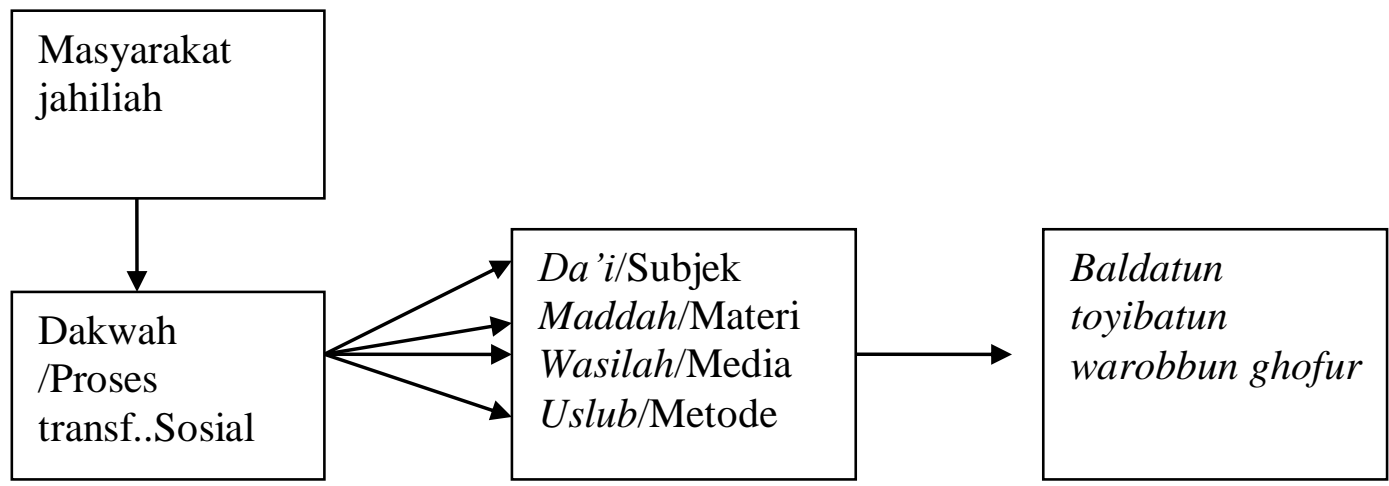

Demikianlah paradigma yang mungkin mampu menjadi gambaran sementara bahwa tujuan akan tercapai ketika memang dalam proses transformasinya benar dan tepat. Akan tetapi jika tidak benar maka sebaliknya.

Dalam hal ini penulis ingin mendekati masalah di atas dengan pendekatan analisis historiy,pendekatan serta sosiologi sebagai penguat. Dengan asumsi adanya relevansi antara normatif teks dengan realita sosial. 


\section{B. KONSEP "Baldatun Thoyibatun Warobbun Ghofur"}

\section{Pengertian}

Baldatun Thoyibatun warobbun Ghofur, dapat didefinisikan sebagai negara yang baik dan mendapat ampunan Allah swt, Al qur'an telah menyebutkanya dalam surat as Saba' ayat 15:

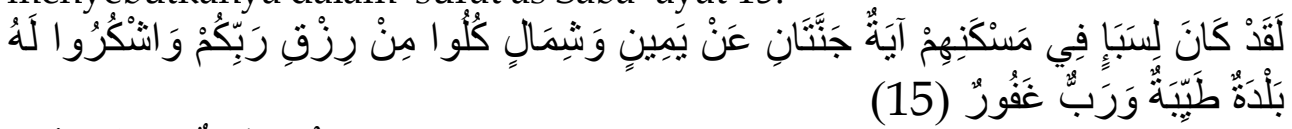


atau daerah yang baik. Kata baldatun berasal dari kata balad secara bahasa biasa diterjemahkan dengan tempat sekumpulan manusia hidup. .Dalam kamus Hans Wehr kata tersebut diterjemahkan dengan Contry, community, village1 Sehingga ketika kata balad disifatkan dengan thoyibah maka sekumpulan manusia yang tinggal disuatu tempat yang mendapatkan kehidupan yang baik, sebagaimana kehidupan yang di dapatkan oleh negeri saba' dalam ayat tersebut.

\section{Kharakter "baldatun Thoyibatun warobbun Ghofur" negeri Saba"}

Sebelum melihat konsep baldatun thoyibatun lebih luas perlu melihat bagaimana kharakter negeri saba', yang secara eksplisit dijelaskan didalam al Qur'an. Ibnu katsir dalam tafsirnya mengungkapkan beberapa keutamaanya. . Negeri yang memiliki bendungan Irom $^{2}$ yang airnya mengalir dari sela-sela dua gunung, kemudian air sungai tersebut berkumpul dibendungan tersebut dengan air hujan . dari situlah masyarakatnya menanam tanaman, sehingga tumbuh subur, sampaisampai ada seorang wanita yang berjalan dibawah pohonya dengan membawa wadah diatas kepala, sehingga buah-buah dipohon tersebut jatuh dan memenuhi wadah tersebut. Di negeri tersebut tidak ada nyamuk dan kuman, saking bersih dan sehatnya, serta mendapat pertolongan Allah swt. Ibnu katsir menyimpulkan bahwa itu semua karena mereka istiqomah untuk mengesakan Allah dan beribadah kepada-Nya, akan tetapi ketika mereka mulai menyembah matahari maka Allah menghancurkan kemakmuranya. ${ }^{3}$

Dapat diambil sebuah kesimpulan bahwa keberhasilan negeri saba', sampai mendapat pujian Allah swt dalam al Qur'an, disebabkan dari ketauhidan dan ketaatan kepada Allah swt, dan kerja keras mereka untuk membangun peradaban ekonomi, adan kesehatan masyarakat. Akan tetapi ketika ketauhida berganti dengan kesombongan mak negeri itupun kembali dihancurkan Allah swt.

${ }^{1}$ Ali nurdin, Qur'anic Society, Jakarta: Penerbit Erlangga, hal .115, 2006

${ }^{2}$ Irom adalah bendungan yang dibuat oleh kaum saba', sebagai sumber air dalam pengelolaan pertanian mereka, yang sebelum adanya bendungan ini jika kemarau maka akan kekeringan jika musim hujan dilanda banjir

${ }^{3}$ Ibnu Katsir, Tafsirul qur'anil adzim, as saba' :15, hal .507, Maktabah Syamilah 


\section{Kharakter "baldatun Thoyibatun warobbun Ghofur" negeri Madinah}

Setelah proses hijrah rasulullah saw, ada sebuah perubahan signifikan dalam peradaban madinah, ada beberapa karakter yang bisa penulis ungkapkan:

a. Negeri yang bersaudara

Kebijakan rasulullah saw setelah hijrah adalah mempersaudarakan ummat islam dari muhajirin ${ }^{4}$ dan Anshor ${ }^{5}$, . konsep persaudaraan adalah konsep mendasar peradaban islam. .Persaudaraan disini bukan hanya persaudaraan dalam arti nasab tapi adalah persaudaraan iman, yang mampu menghancurkan batas territorial, faham, golongan ataupun yang lainya. Sehingga ummat islam ketika itu satu sama lain sangat kuat, rela dan ikhlas dalam membantu saudaranya, sehingga negeri madinah adalah negeri yang penuh dengan kedamaian dan cinta.

b. Konstitusi yang damai

Kontitusi adalah salah satu unsur negeri madinah, dengan konstitusi madinah dapat mendamaikan beberapa konflik dan sengketa baik para qobilah yang ada ketika itu ataupun hubungan ummat islam dengan ummat non islam. Konstitusi itu menetapkan prinsip Negara modern, seperti kebebasan beragama, kebebasan menyatakan pendapat, perllindungan terhadap harta dan jiwa anggota masyarakat, dengan konstitusi inilah madinah dan sekitarnya telah benar-benar jadi terhormat bagi seluruh penduduknya.

c. Kesetaraan bagi semua warga

Negara madinah adalah Negara yang memberikan jaminan keamanan kepada kelompok minoritas (zimmi) dengan nyawanya sendiri. Beliau pernah mengatakan bahwa siapa yang menganiaya kelompok minoritas tersebut maka telah menganiaya rasulullah juga. (Sahih Bukhori, 6951) Tidak ada perbedaan status hak dan kewajiban antara orang arab dab ajam, pendatang dan penduduk asli madinah. Semua diperlakukan sama didepan hukum dan sebagai warga Negara dengan hak dan kewajiban masing-masing. ${ }^{6}$

d. Pendidikan yang sempurna

Dalam membngun Madinah, nabi Muhammad saw sangat memperhatikan pendidikan, ketika usai perang badar, 70 orang Quraisy yang menjadi tawanan, diberikan tebusan bebas dengan mengajarkan ilmu baca tulis terhadap 700 anak muslim, dan angka ini

\footnotetext{
${ }^{4}$ Orang muhajirin adalah orang yang ikut hijrah dari Makkah ke Madinah

${ }^{5}$ Orang anshor adalah orang yang tinggal di Madinah yang menolong dan membantu orang muhajirin

${ }^{6}$ Dr. Muhammad Syafii Antonio,M.Ec, MuhammadThe Super Leader Super Manager, Jakarta:ProLM, hal.156, 2007
} 
terus membesar karena masing-masing mereka mengajarkan kepada yang lainya, sehingga buta huruf bisa diselesaikan ${ }^{7}$

e. Menguasai diplomasi Politik luar negri

Ada beberapa urusan politik luar negri yang menjadi symbol kekuatan politik luar negri madinah, yaitu pada kasus perjanjian hudaibiyah dan pengutusan diplomatic politik ke berbagai Negara. Dalam perjanjian hudaibiah ummat islam mampu memenangkan diplomasi dan merubah image negative Negara lain. Keberhasilan itu meliputi, pengakuan quraisy terhadap kerasulan Muhammad, mengakui kaum muslimin dan wargamadinah untuk memasuki kota makkah dan berhaji, secara tidak langsung mengakui islam, menjadikanm madinah sebagai kekuatan politik baru yang diperhitungkan di jazirah arab, ummat islam tenang dalam ibadah dan dakwah. Selain kemenangan itu rasulullah juga mengirimkan utusan diplomatic keberbagai Negara untuk menyampaikan dakwah, dan sebagai bentuk sosialisasi keberadaan Negara madinah. Sehingga madinah menjadi Negara yang diakui dan disegani. ${ }^{8}$

f. Ekonomi yang mensejahterakan

Kekuatan suatu Negara tidak dapat dipisahkandari pengaturan system ekonomi untuk mensejahterakan warganya. Ada beberapa langkah strategis dalam penanggulangan ekonomi ini, yang pertama adalah melarang riba ${ }^{9}$, gharar (menipu) ${ }^{10}$, ihtikar (penimbunan ${ }^{11}$ ), tadlis (penyembunyian) ${ }^{12}$ dan market inefficiency ${ }^{13}$ Madinah adalah juga Negara yang memiliki system kebijakan fiscal dan keuangan public yang jelas.

g. Keamanan yang terjamin

Dalam mempertahankan Madinah Nabi Muhammmad saw memutuskan untuk membentangkan kekuasaan kaum muslimin dijalur perdagangan dari Makkah ke Syiria (syam). Langkah -langkah yang ditempuh antara lain, mengadakan perjanjian aliansi dan perdamaian dengan kabilah-kabilah yang tinggal diantara jalur perdagangan itu, atau kabilah-kabilah yang tinggal diantara jalur tersebut dan madinah. Yang kedua adalah melakukan ekspedisi-

\footnotetext{
${ }^{7}$ Ibid

${ }^{8}$ Ibid

${ }^{9}$ Riba' adalah prilaku pinjam meminjam uang dengan tambahan yang ditentukan dan hal ini sangat merugikan bagi peminjam

${ }^{10}$ Ghoror adalah ketidak fairan dalam memberikan informasi dalam jual beli, baik informasi kualitas, kwantitas, harga dan waktu,

${ }^{11}$ Ihtikar adalah segala bentuk prilaku dalam jual beli yang membauat effek negative dalam penyediaan barang, baik menimbun atau memonopoli

${ }^{12}$ Tadlis adalah menyembunyikan cacat barang

${ }^{13}$ Market Inefficincy adalah tidak adanya informasi yang sama dalam jual beli, ehingga sebagian yang alin dirugikan karena ketidak tahuanya.
} 
ekspedisi secara bergantian kejalur-jalur tersebut. Strategi ini dengan tujuan untuk memberikan kesan kepada orang-orang Yahudi dan arab badui yang berdomisili di sekitar Madinahbahwa kaum muslim telah memiliki kekuatan dan mereka telah terbebas dari kelemahan

h. Keadilan Hukum

Dalam menjaga dan mengatur Negara madinah, Rasulullah didukung dengan kekuatan hukum yang adil, kekautan hokum yang benarbenar sesuai dengan karakter dan fitrah manusia.. Hukum yang benarbenar terlaksana. Hukum yang diterapkan pada Negara Madinah ,memiliki karakter yang sangat sempurna, diantaranya adalah , rabbaniyah (bersandar pada nilai ketuhanan), tadarruj (bertahap), umum (general), ideal dan realistis, washitiah (moderat), murunah (flexible), al Adalah (adil), rof'ul haraj (tidak sukar) qillatu al-taklif (meminimalisir kewajiban hukum), jalbu al-Mashalih (menarik maslahat) , takmul/syumul (comprehenshive). Karakter-karakter itulah yang telah mengantarkan kepada keadilan madinah, sehingga terjadi kehidupan yang tawazun (seimbang) tidak ada kesenjangan antara pihak elit ataupunmasyarakat biasa. ${ }^{14}$

i. Ketaatan beragama

Madinah sebelum dideklarasikan menjadi sebuah kekuasaan politik legal, adalah menjadi pusat agama Islam, sebagai spiritual centre (pusat kerohanian) ummat Islam. Sehingga dapat dilihat bagaimana ketaatan para sahabat nabi, dan penduduk Madinah ketika itu. Kehidupan agamis islamilah yang nampak di Madinah, bukti sejarah ini telah dapat dilihat dari banyak literature. 15

Karakter diatas adalah karakter Negara yang disebut baldatun thoyibatun warobbun ghofur, karakter yang sangat universal, dan berlandaskan pada nilai bukan formal. Berlandaskan pada tauhid bukan pada matrialisme, itulah yang menyebabkan suatu Negara menjadi eksit dan kuat, akan tetapi bial landasan itu telah hilang maka akan mendatangkan kerusakan yang membawa kepada kesengsaraan ummat manusia.

\section{Negara dalam pandangan Ibnu Khaldun}

\footnotetext{
${ }^{14}$ Ibid

${ }^{15}$ Shafiyurrahman al Mubarrak Furry, Ar Rahiqul Makhtum, Jakarta: al Kautsar: 251,
} 
Ibnu Khaldun menemukan suatu tipologi negara dengan tolok ukur kekuasaan (al mulk). Ia membagi negara menjadi dua kelompok yaitu :

1. Negara dengan ciri kekuasaan alamiah (mulk tabi'i) atau negara tradisional

2. Negara dengan ciri kekuasaan politik (mulk siyasi) atau negara modern. ${ }^{16}$

Tipe negara alamiah ditandai oleh kekuasaan yang sewenang-wenang dan otoriter (despotisme) dan cenderung kepada "hukum rimba". Di sini keunggulan dan kekuatan sangat berperan. Hukum hanya dipakai untuk menjerat leher rakyat yang tertindas, sementara elit penguasa bebas melakukan dosa dan maksiat sesukanya dan prinsip keadilan diabaikan. Baik keadilan ekonomi maupun keadilan sosial-politik. Ia menyebut negara alamiah seperti ini sebagai negara yang tidak berperadaban (uncivilized state).

Sementara itu, tipologi negara modern yang berdasarkan kekuasaan politik dibaginya menjadi tiga macam yaitu (1) negara hukum atau nomokrasi Islam (siyasah diniyah), (2) negara hukum sekuler (siyasah 'aqliyah), dan (3) negara "Republik" ala Plato (siyasah madaniyah). Negara Madani yang disebutkan terakhir adalah sebentuk negara sekuler yang dipertahankan oleh orang-orang Islam yang bekerja sama bahu-membahu dengan orang-orang kafir dalam membentuk suatu "negara musyrik".

Dari ketiga tipologi Negara di atas yang paling ideal adalah tipologi Negara hukum atau siyasah diniah, karena berdasarkan dengan syari'at, yang menginginkan kehidupan yang sejahtera, kehidupan yang dapat dirasakan oleh semua masyarakat, bukan hanya dirasakan oleh para elit politikus, atau bukan hanya Negara yang mementingkan kehidupan materi seperti Negara sekuler. Tipologi inilah yang disebut sebagai baldah toyibah.

\section{Realisasi Baldatun Thoyibatun warobbun Ghofur}

Konsep baldatun tahoyibatun warabbaun ghofur tidak bisa hanya menjadi sebuah konsep normatif, tetapihendaknya adanya sebuah gerakan untuk mencapainya. Indonesia adalah Negara yang memiliki potensi besar bagi terwujudnya negeri dambaan ini. Ada beberapa langkah bagi terwujudnya baldatun thoyibatun wa rabbun ghofur:

1. Mencapai baldatun tahoyibatun warabbaun ghofur dalam pendekatan social

Dalam pendekatan sosial ada beberapa faktor perubahan sosial, diantaranya adalah kontak dengan kebudayaan, sistem pendidikan 
formil yang maju, orientasi ke masa depan ${ }^{17}$ proses perubahan bangsa Indonesia menuju negeri yang baldatun thoyibatun wa rabbun ghafur, seperti gambaran diatas, membutuhan sebuah proses yang panjang. Yang pertama hendaklah bangsa Indonesia membangun kontak peradaban dengan bangsa maju yang memiliki karakter baldah toyibah, dan mengambilnya serta mengembangkanya di negeri ini. .Yang kedua bangsa Indonesia harus mengedepankan pendidikan formal yang berkualitas, pendidikan yang komprehensif bukan yang sekuler, yang mampu mensinergikan antara kebutuhan intelektual dan spiritual, teori dan praktek. Yang terakhir adalah dengan membangun motivasi untuk hidup maju kepada ummat islam dan bangsa Indonesia, sehingga akan melahirkan masyarakat yang bervisi tinggi.

2. Mencapai baldatun tahoyibatun warabbaun ghofur dalam pendekatan dakwah

Dakwah adalah syari'at Allah swt yang perintahkan sebagai wasilah perubahan masyarakat, sebagaimana Allah swt berfirman: Hendaknya ada diantara kalian segolongan ummat yang mengajak kepda kebaikan memerintahkan yang ma'ruf dan mencegah yang munkar. Merekalah orang yang beruntung"(ali Imron :104) ayat inilah yang menjadi asas perubahan ummat, bagaimana ummat islam mengajak manusia kepada jalan Allah, mengajak manusia kepada suatu Negara yang baik serta mengaplikasikanya.

Dalam proses dakwah ada fiqih perubahan (fighut Taghyir) yang harus diperhatikan, dengan melihat keadaan awal sebelum dilakukan perubahan, kemudian menentukan tehnik perubahanya.. ada beberapa tahapan perubahan:18

\section{a. Perubahan Internal}

Perubahan internal adalah perubahan yang pertama harus dilakukan untuk membentuk negara ideal, perubahan internal adalah perubahan ber-spirit qur'ani dari firman Allah swt:" Allah tidak akan merubah keadaan suatu kaum sehingga mereka merubah keadaan yang ada pada diri mereka sendiri." (ar Ra'du: 11) kaidah al Qur'an ini adalah menyatakan kepada ummat manusia" Rubahlah dirimu, maka sejarah akan berubah" Mustafa Masyhur juga mengatakan:" tegakkan islam dalam dirimu, maka islam akan tegak di dunia ini"

Kaidah inilah yang telah mengantarkan para pembaharu muslim dalam melakukan perubahan, contoh Rasyid Ridho, Abduh, Hasan al Banna, dan masih banyak lagi. Dalam petunjuk nabawiy dapat difahami secara sosio histories, bahwa nabi Muhammad saw dalam merubah

${ }^{17}$ Soerjono Soekanto, sosiologi Suatu Pengantar, Jakarta: Rajawali Press, hal. 335,

${ }^{18}$ Dr. yusuf al Qaradhawi, Pedoman Bernegara dalam prespektif Islam, Jakarta: al Kautsar, hal .286, 1999 
bangsa arab adalah dengan cara menuntun mereka untuk menyembah Allah swt, meninggalkan paganisme menuju tauhid, dari kesesatan menuju petunjuk, dari permisivisme menuju kepada takwa, dari kebebasan ke aturan, dari materialism eke rabbaniyah. Pada akhirtnya membawa manusia dari peradaban jahiliah menuju peradaban Negara yang baldah thoyibah.

Dakwah saat ini hendaknya kembali mengikuti manhaj nubuwah, bukan memulai perbaikan pada aspek - aspek materi saja akan tetapi mulai membangun paradigma baru membangun mental spiritual bangsa yang harus dikedepankan.

\section{b. Perubahan Eksternal}

Perubahan eksternal adalah perubahan system struktur birokrasi yang telah mengalami kerusakan, karena system yang dibangun dinegri ini adalah system interest (kepentingan) individu atau golongan. Perubahan pada hirarki ini adalah perubahan oleh para elit politik yang telah terbangun pemikiran dan visinya untuk terwujudnya kemajuan hakiki, Negara yang baldatun thoyibatun warobbun ghofur.

\section{E. Kesimpulan}

Kajian ini dapat disimpulkan bahwa Negara yang baldatun thoyibatun warabbun ghofur adalah Negara yang makmur dalam setiap bidangnya, karena dilandaskan dengan dasar tauhid. Baik bidang social, budaya, politik, ekonomi, pendidikan maupun hak asasi manusia.

Dalam merealisasikan bentuk Negara tersebut membutuhkan sebuah tahapan yang hendaknya diperhatikan oleh para pelaku perubahan, sebagaimana rasulullah saw melakukan perubahan. Perubahan tersebut dapat dilakukan dengan melakukan perubahan internal maupun eksternal. 


\section{DAFTAR PUSTAKA}

Katsir Ibnu, Tafsirul qur'anil adzim, as saba' :15, , Maktabah Syamilah Syafii Antonio Dr. Muhammad,M.Ec, MuhammadThe Super Leader Super Manager, Jakarta:ProLM, , 2007

al Mubarrak Furry Shafiyurrahman, Ar Rahiqul Makhtum, Jakarta: al Kautsar: 1997

Soekanto `Soerjono, sosiologi Suatu Pengantar, Jakarta: Rajawali Press, , 1982 al Qaradhawi, Dr. Yusuf Pedoman Bernegara dalam prespektif Islam, Jakarta: al Kautsar, 1999

Ali nurdin, Qur'anic Society, Jakarta: Penerbit Erlangga, , 2006 